\title{
Production of Cost Effective, Biodegradable, Disposable Feminine Sanitary Napkins using Banana Fibres
}

\author{
Priya Petchimuthu, Ramya Petchimuthu, Sarah Afreen Basha, Ramya Krishnaveni Murugan, \\ Harshi Sundara Ganapathy, Uma Maheshwari Durairaj
}

\begin{abstract}
Women all around the world use sanitary napkins for menstrual protection. In India, only small percentage of women uses sanitary napkins. The main reason for such a low number relates to the affordability of the people. Sanitary napkins that are available now are non-biodegradable and also cause severe infections there by affecting women's health. To overcome this challenge, sanitary bio napkins are made from natural materials. In the present study, naturally available cheap materials like banana fiber and cotton which are easily available, biodegradable and cost effective were used. Another advantage of using the natural materials was their characteristics like porosity and retention of fluid for a longer time. The results indicated that the napkins are ecofriendly and it shows no negative effects to women around the village.
\end{abstract}

Keywords : Biodegradable, Bio napkins, Banana fibers.

\section{INTRODUCTION}

$\mathrm{N}_{\mathrm{o}}$ eco-friendly environment by reducing the environmental problems and nature pollution. Besides, health and hygiene is also very much important for human beings. The utmost pollutions are from textile industry, dye industry and healthcare industry [2]. Among these, healthcare wastes are the major pollution that will create deliberate complications to the humans. One major problem is the manufacturing and clearance of sanitary napkins. The napkins produced by the companies which are not degradable and unsafe for women's. Sanitary napkins should provide comfort and safety, and also improve every woman's health and lifestyle. Women place these napkins next to the most delicate and absorbent tissue in our body. Women spend at least $20 \%$ of their life with these sanitary napkins. India being a developing country, having 1.34 billion populations, in those 323.6 million peoples is female between the age group of 15-49 [7]. In previous years, papyrus, Moss, grass, Bandages were used during menstrual time and these materials can causes Irritation, Itchiness Skin rashes, allergy and lead to very serious health problems due to the presence of

Revised Manuscript Received on December 16, 2019

* Correspondence Author

Priya Petchimuthu*, Ramya Petchimuthu are with the Department of Biotechnology, Kalasalingam Academy of Research and Education, Virudhunagar, Tamilnadu, India. Email: ppriyabt@gmail.com, p.ramya@klu.ac.in

Sarah Afreen Basha, Ramya Krishnaveni Murugan, Harshi Sundara Ganapathy, Uma Maheshwari Durairaj are with the Department of Biotechnology, Kalasalingam Academy of Research and Education, Virudhunagar, Tamilnadu, India. Email: sarahafreen5@gmail.com, ramyastr76@gmail.com, harshihks18@gmail.com, duraifire.k@gmail.com.

microorganisms. Manufacturers also add chemicals in the scented napkins that can cause complications not only the women who is wearing it and also to the babies during embryonic development. In order to overcome these problems, here we are proposing sustainable sanitary napkins by choosing alternative natural material for the production. In the present study, an attempt has been made to produce sanitary napkins from banana fiber, a natural absorbent fiber. It is expected that incorporation of banana fibers grant antibacterial property and improve the retentiveness [4]. Other important properties like antioxidant, bio degradable, UV protection, weather protection. It has no negative effect on environment and it is considered as eco-friendly fiber.

\section{MATERIALS AND METHODOLOGY}

\section{A. Materials:}

Sanitary napkins contain multilayered structure and each layer should have some specific function. Banana fiber, organic cotton, muslin cloth and canvas cloth were used as a source of material. Banana fiber is naturally occurring material and completely degradable and poses no side effect to humans and environment [3] Organic Cotton as top layer is one the generally prompted crude material in napkin due to its non-aggravation, tissue-friendly and prevalent fluid maintenance properties.[1] Cotton material keeps away moisture and keeps skin dry and make skin comfort $[5,6]$

\section{B. Methodology:}

\section{PREPARATION OF BANANA Fiber SHEET}

The banana fibers are extracted from the stem of the banana tree and was cut into tiny pieces. The small banana fiber pieces were taken in the vessel or beaker and allow it to boil with water for an hour. To this, sodium hydroxide was added. Later, it was filtered using a filter paper and the mixture was poured onto a mold of a required shape and let too dry under sunlight for a day. The banana sheet is formed after drying.

\section{SOFTENING OF CANVAS ClOTH}

Canvas cloth is used as a top layer in the sanitary napkin. It is usually used in making collar of shirts to maintain stiffness. To remove the starch from the cloth we have to soften by scrubbing it with brush so that the pore size will be increased and this also increasing the pore size of the cloth. 


\section{LAYERING OF SANITARY NAPKIN}

Sanitary pad comprises of multilayered structure in which each layer have explicit capacity to perform [1]. The Banana fiber sheet is wrapped up with organic cotton which is covered with Muslin cloth. The whole setup is again wrapped up with a Canvas cloth.

\begin{tabular}{|c|}
\hline CANVASCLOTH \\
\hline MUSLIN CLOTH \\
\hline COTTON \\
\hline BANANAFIBRE \\
\hline COTTON \\
\hline MUSLIN CLOTH \\
\hline CANVASCLOTH \\
\hline
\end{tabular}

Fig 1: Napkin layout

\section{RESULTS}

\section{A. Survey}

A survey was taken from students and staff workers of our University randomly. The online survey and also the researchers interacted with the students and staffs directly and the demands were noted in the survey form which researchers developed. Our product was designed according to their demands. According to our survey, women prefer napkins that have absorbance of 3-4 hours and they are willing to try different brands that are chemical free. The output was documented.

The survey pictures are as follows:
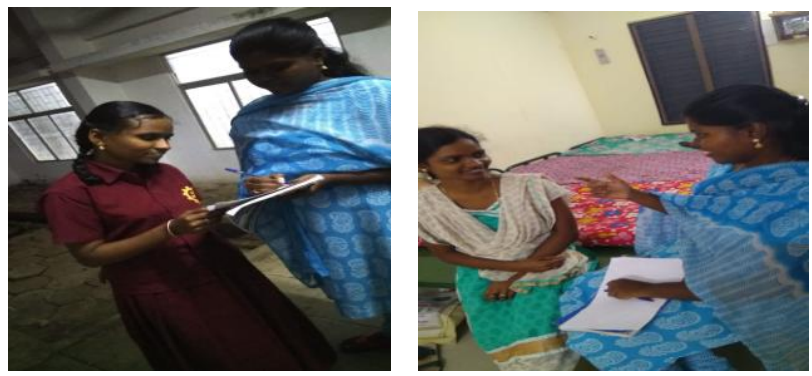

Fig 2. Field Survey

\section{B. Extraction of Fiber}

- Extraction of banana Fiber from the pseudo stem of the plant was done manually.

Fig.3. Collection of banana stem
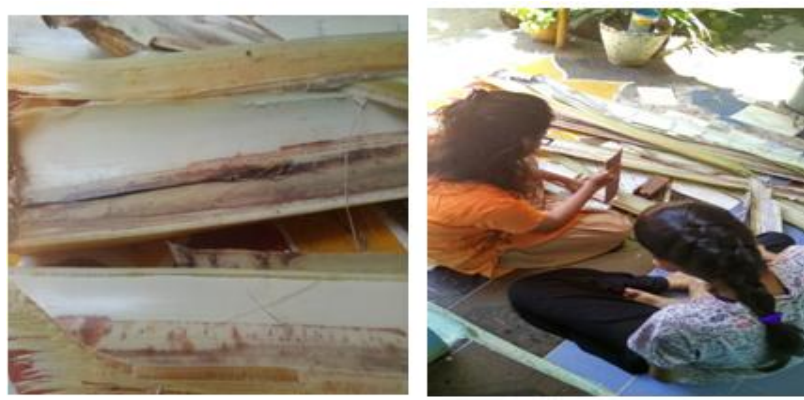

Fig 4: Extraction of fibers

\section{Processing of fibres}

After extraction, the fibers are made to cut into fine chops and then it was allowed to boil with $150 \mathrm{~mL}$ of distilled water and 5 gram of sodium hydroxide for an hour. The mixture was cooled for about 1 and half hour to make a thin sheet.

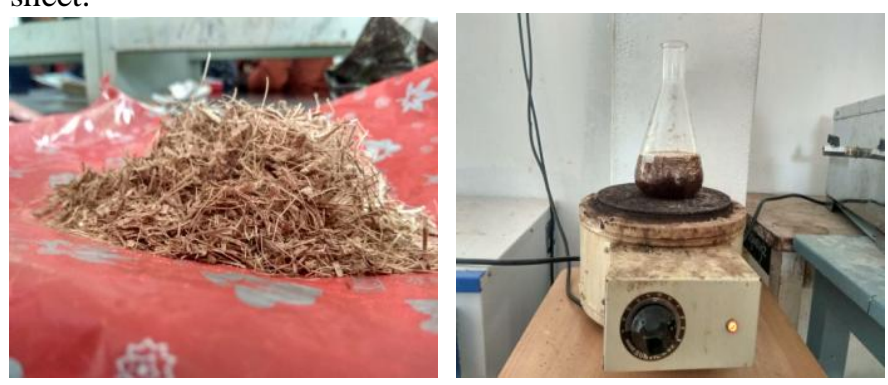

Fig. 5. Fiber processing

\section{Packaging of napkin}

The organic cotton was placed on to the thin banana sheet and then it was covered by the muslin cloth. The softened canvas cloth was used to wrap the entire sheets and then the corner of the canvas cloth in the napkin was allowed to stick using heat or else stitches can be made in the corner of the napkin.
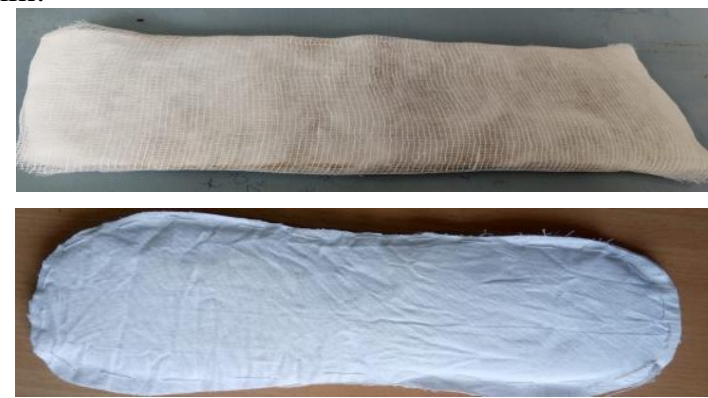

Fig 6: Sanitary napkin

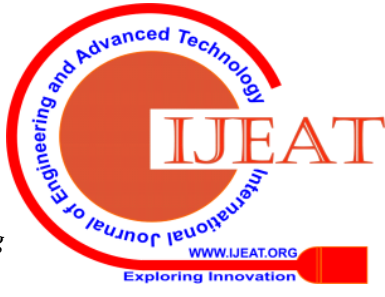




\section{E. Testing of Parameters}

The primed napkins after UV Sterilization were tested by the researchers who developed the product and the results were good and then the samples were distributed to others.

\begin{tabular}{|c|l|}
\hline Parameters & \multicolumn{1}{|c|}{ Observation } \\
\hline $\begin{array}{c}\text { Absorbance } \\
\text { capacity }\end{array}$ & $\begin{array}{l}\text { 25 ml of goat blood was absorbed } \\
\text { when flowed on the centre of the } \\
\text { napkin. No stain or spillage will } \\
\text { appear at the base or sides of the } \\
\text { sanitary napkin }\end{array}$ \\
\hline $\begin{array}{c}\text { Acidity and } \\
\text { Alkalinity }\end{array}$ & pH 7.5-8.5 \\
\hline Fluorescence & No Fluorescence \\
\hline $\begin{array}{c}\text { Dispersibility } \\
\text { Size of the } \\
\text { sanitary } \\
\text { napkins }\end{array}$ & $\begin{array}{l}\text { Fmall size: } 200 \mathrm{~mm} \\
\text { Large size: } 260 \mathrm{~mm}\end{array}$ \\
\hline
\end{tabular}

\section{F. Distribution of Sanitary napkin}

The sample napkins were distributed to the people in villages and the feedback was recorded continuously. The villagers felt that the product has an absorbance capacity of 5 hours and, no rashes or foul smell was observed by them.

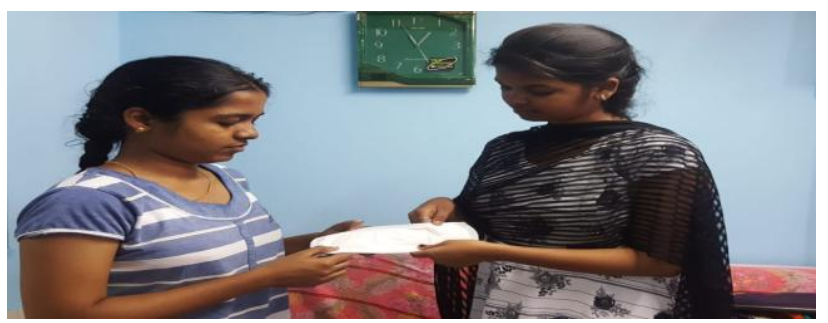

Fig.7. Sample napkin distribution

\section{CONCLUSION AND FUTURE WORK}

Recently, natural resources are gaining attention in solving the problems faced by the people around the world. This study proved that the replacement of non-degradable material with the biodegradable material for developing hygienic feminine products is ecofriendly and cost effective. Use of natural material in napkins will be cost effective and it can be affordable by the lower income people. Using this technology, we can find a suitable solution to make the world better for future generation.

\section{ACKNOWLEDGEMENT}

The authors wish to acknowledge the Management of Kalasalingam Academy of Research and Education for providing an opportunity to complete this research work.

\section{REFERENCES}

1. Barman A*, Katkar PM and Asagekar SD. "Natural and Sustainable Raw Materials for Sanitary Napkin", Textile Sci Eng, 2017, 7:3

2. Dhinakaran M, Senthil CS, Sathis TK (2017) "Development and characterization of sanitary napkins with Lyocell/Modal as absorben core". International Research Journal of Engineering and Technology 4 1003-1006.

3. C.Vigneshwaran, V.Pavithra, V.Gayathri and K.Mythili: Banana fiber: Scope and Value Added Product Development vol.9 issue 2, spring2015

4. O. L. Shanmugasundaram, R V M Gowda, "Development and Characterization of Bamboo and Organic Cotton Fibre Blended Baby
Diapers" Indian Journal of Fibre \& Textile Research, Vol.35, pp.201-205, Sept.2010.

5. Pepper LR, Dumain J (2016) Textile exchange organic cotton market report.

6. Pohlmann M (2016) Design and materials selection: analysis of similar sanitary pads for daily use. International Journal of Engineering Research and Application 6: 74-79.

7. World populations review (2017) World population by country

\section{AUTHORS PROFILE}

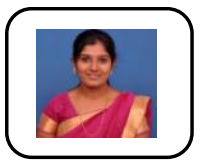

P.Priya received B.Tech in Biotechnology at Kalasalingam University in May 2011, and M.Tech Biotechnology in Kalasalingam University May 2013. Currently working as Assistant Professor in Biotechnology department at KARE, Krishnankoil. Research interest are Microbiology and Microbial enzymes.

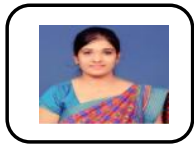

P.Ramya received B.Tech in Biotechnology at Kalasalingam University in May 2011, and M.Tech Biotechnology in Mepco schlenk Enginnering College, Sivakasi May 2013. Currently working as Assistant Professor in Biotechnology department at KARE Krishnankoil. Research interest are bioprocess and biochemical engineering

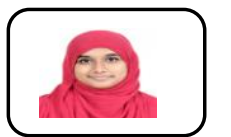

Sarah Afreen Basha, pursuing her B.Tech Biomedical Engineering at Kalasalingam Academy of Research and Education, Krishnankoil

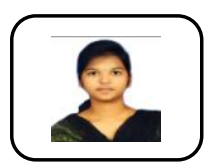

Ramya Krishnaveni Murugan pursuing her B.Tech Biomedical Engineering at Kalasalingam Academy of Research and Education, Krishnankoil.

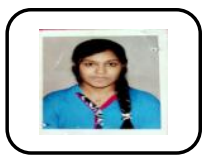

Harshi Sundara Ganapathy pursuing her B.Tech Biomedical Engineering at Kalasalingam Academy of Research and Education, Krishnankoil.

Uma Maheshwari Durairaj, pursuing her B.Tech Biomedical Engineering at Kalasalingam Academy of Research and Education, Krishnankoil. 